\title{
Why Belief Statements Are Not Truth-Functional
}

\author{
Keith Burgess-Jackson \\ The University of Texas at Arlington, Arlington, Texas, USA
}

\begin{abstract}
Truth-functionality is the most important concept in propositional logic. Some compound propositions are truth-functional and some are not. In this essay, I explain the difference between truth-functional compound propositions and non-truth-functional compound propositions, using what I call "belief statements" as an example of the latter. My explanation of why belief statements are not truth-functional is both more thorough and (I submit) more illuminating than the explanations provided by the leading logic textbooks. The authors of these textbooks may wish to incorporate some of my suggestions into future editions. Alternatively, they may direct their students to this essay for edification.
\end{abstract}

Keywords: logic, propositional logic, truth-functionality, truth-functions, belief, belief statements

\section{Introduction}

Nowhere in the whole structure of standard logic are the non-truth-functional sorts of statement composition systematically analyzed. Nowhere are general techniques developed for determining truth values of non-truth-functional compounds of statements. Each individual example tends rather to present individual problems and to call for individual treatment. (Quine, 1980, pp. 23-24)

Truth-functionality is the most important concept in propositional logic. Some compound propositions are truth-functional and some are not. What is the difference? Most textbook authors explain the difference by giving examples of each type of proposition. One of the most common examples provided of a non-truth-functional compound statement is what I call a "belief statement." Here is Irving M. Copi:

Not every compound statement is truth-functional. ... For example, the truth value of the compound statement "Othello believes that Desdemona loves Cassio" is not in any way determined by the truth value of its component simple statement "Desdemona loves Cassio," for it could be true that Othello believes that Desdemona loves Cassio regardless of whether she does so or not. A person who believes one truth need not believe another, and a person can believe one falsehood without believing all of them. So the component "Desdemona loves Cassio" is not a truth-functional component of the statement "Othello believes that Desdemona loves Cassio," and the latter is not a truth-functional compound statement. (Copi, 1982, p. 280)

Here is Patrick J. Hurley:

Many compound propositions in ordinary language are not truth functions. For example, the statement "Mary believes that Paul is dishonest" is compound because it contains the statement "Paul is dishonest" as a component. Yet the truth value of the compound statement is not determined by the truth value of the component, because Mary's beliefs about Paul are not compelled by any attribute that Paul may or may not possess. (Hurley, 2016, p. 250)

Keith Burgess-Jackson, J.D., Ph.D., is Associate Professor of Philosophy in the Department of Philosophy and Humanities at the University of Texas at Arlington. He is the author of many books, articles, book chapters, encyclopedia entries, and book reviews in logic, ethics, philosophy of religion, biomedical ethics, philosophy of law, and social and political philosophy. 
Here is Stan Baronett:

\begin{abstract}
Not all ordinary language compound propositions are truth-functional. For example, the statement "Paul believes that Rhonda loves Richard" is not determined by the truth value of its components. The simple component statement "Rhonda loves Richard" could be true or false. But neither of the two possible truth values determines the truth value of the compound statement "Paul believes that Rhonda loves Richard." This follows because Paul might believe that Rhonda loves Richard whether or not Rhonda actually loves Richard. Therefore, the truth value of the simple component "Rhonda loves Richard" is not a truth-functional component of the compound statement, and the compound statement "Paul believes that Rhonda loves Richard" is not truth-functional. (Baronett, 2019, p. 338 [italics in original])
\end{abstract}

The textbook explanations could stand improvement, if for no other reason than that they're short. The purpose of this essay is to provide a more thorough and more illuminating explanation of why belief statements 1 - i.e., statements of the form ' $\mathrm{S}$ believes that $\mathrm{p}$ ' - are not truth-functional. The essay is written for instructors, but students should find it useful as well.

\title{
Truth-Functionality
}

The first thing to notice about belief statements is that they are compound. A statement is compound, as opposed to simple, if and only if (1) it contains a statement other than itself as a component and (2) it remains meaningful when the component is replaced by any other statement. The statement ' $\mathrm{S}$ believes that $\mathrm{p}$ ' contains a statement other than itself (namely, ' $p$ ') as a component and remains meaningful when ' $p$ ' is replaced by any other statement (such as ' $\mathrm{q}$ '). Therefore, ' $\mathrm{S}$ believes that $\mathrm{p}$ ' is a compound statement.

A compound statement is truth-functional, as opposed to non-truth-functional, if and only if its truth value is determined by (1) the truth values of its components and (2) the meaning of any logical operators it contains. Belief statements contain no logical operators. Therefore, a belief statement is truth-functional if and only if its truth value is determined by the truth values of its components, in this case ' $p$ ' (the proposition believed).

\section{Why Belief Statements Are Not Truth-Functional}

So let us ask: Is the truth value of 'S believes that p' determined by the truth value of ' $\mathrm{p}$ '? The answer is no. Let me explain why.

Suppose ' $\mathrm{p}$ ' is true. ' $\mathrm{S}$ believes that $\mathrm{p}$ ' may be either true or false. Consider the following pair of statements:

- 'Keith [the author of this essay] believes that Donald J. Trump is the 45th president' is true.

- 'Jethro ${ }^{2}$ believes that Donald J. Trump is the 45 th president' is false.

The proposition that Donald J. Trump is the 45th president is true. The first example shows that one can believe a true proposition. (I do indeed believe that Donald J. Trump is the 45th president.) The second example shows that one can fail to believe (or even disbelieve) a true proposition.

Now suppose ' $p$ ' is false. 'S believes that $p$ ' may be either true or false. Consider the following pair of statements:

\footnotetext{
1 I use the words "statement" and "proposition" interchangeably.

2 Jethro Bodine was a character (played by Max Baer Jr) in the American television series The Beverly Hillbillies, which aired from 1962 to 1971. Jethro was, according to Wikipedia, “dim-witted." Let's assume that Jethro doesn't pay much attention to politics. He was told by a prankster friend that Hillary Rodham Clinton defeated Donald J. Trump in the 2016 presidential election. Gullible as he is, Jethro came to believe that Hillary Rodham Clinton is the 45th president and to disbelieve that Donald J. Trump is the 45th president. To disbelieve a proposition is to believe it to be false. So Jethro believes that Hillary Rodham Clinton is the 45th president and also believes that Donald J. Trump is not the 45 th president.
} 
- 'Jethro believes that Hillary Rodham Clinton is the 45th president' is true.

- 'Keith believes that Hillary Rodham Clinton is the 45th president' is false.

The proposition that Hillary Rodham Clinton is the 45th president is false. The first example shows that one can believe a false proposition. The second example shows that one can fail to believe a false proposition. (I do not believe, indeed I disbelieve, that Hillary Rodham Clinton is the 45th president.)

Here is a summary of these results:

\begin{tabular}{llll}
\hline & & 'p' \\
\cline { 3 - 4 } & & True & False \\
\hline \multirow{3}{*}{ 'S believes that $\mathrm{p}$ ' } & True & 1. Keith believes that Donald J. Trump & 2. Jethro believes that Hillary Rodham \\
& & is the 45th president. & Clinton is the 45th president. \\
& False & 3. Jethro believes that Donald $\mathbf{J}$. & 4. Keith believes that Hillary Rodham \\
& & Trump is the 45th president. & Clinton is the 45th president. \\
\hline
\end{tabular}

One can believe a true proposition (category 1), believe a false proposition (category 2), fail to believe a true proposition (category 3), and fail to believe a false proposition (category 4). Obviously, it is good to believe true propositions and to fail to believe false ones, just as it is bad to believe false propositions and to fail to believe true ones. Ideally, one would believe all and only true propositions. Perhaps only God (if there is a god) satisfies this ideal. The most that fallible human beings can hope for is to increase the number of true beliefs they have and to decrease the number of false beliefs they have.

\section{An Alternative Explanation}

Here is an alternative explanation of why belief statements are not truth-functional. Proposition $\mathrm{X}$ is independent of proposition $\mathrm{Y}$ (i.e., $\mathrm{X}$ and $\mathrm{Y}$ are independent [of one another]) if and only if (1) it is possible for $\mathrm{X}$ to be true while $\mathrm{Y}$ is false; (2) it is possible for $\mathrm{Y}$ to be true while $\mathrm{X}$ is false; (3) it is possible for both $\mathrm{X}$ and $\mathrm{Y}$ to be true; and (4) it is possible for both $\mathrm{X}$ and $\mathrm{Y}$ to be false. Let $\mathrm{X}$ be the proposition ' $\mathrm{S}$ believes that $\mathrm{p}$ ' and let $\mathrm{Y}$ be the proposition ' $\mathrm{p}$ '. These propositions are independent (of one another), as the following examples show:

1. It is possible for ' $S$ believes that $p$ ' to be true while ' $p$ ' is false. Example: Jethro believes that Hillary Rodham Clinton is the 45th president.

2. It is possible for 'p' to be true while 'S believes that p' is false. Example: Jethro believes that Donald J. Trump is the 45th president.

3. It is possible for both 'S believes that p' and 'p' to be true. Example: Keith believes that Donald J. Trump is the 45 th president.

4. It is possible for both ' $\mathrm{S}$ believes that $\mathrm{p}$ ' and ' $\mathrm{p}$ ' to be false. Example: Keith believes that Hillary Rodham Clinton is the 45th president.

To say that ' $\mathrm{S}$ believes that $\mathrm{p}$ ' is independent of ' $\mathrm{p}$ ' is to say that there is no dependency relation between them. This is another way of saying that the truth value of one of them is not determined by the truth value of the other, from which it follows that the truth value of ' $\mathrm{S}$ believes that $\mathrm{p}$ ' is not determined by the truth value of 'p'. Belief statements are not truth-functional.

\section{Complicating the Discussion}

To this point in the essay, I have assumed that there are just two possible relations between a believing subject (S) and a proposition (p), namely, belief and non-belief. Actually, there are three possible relations. For 
any subject $\mathrm{S}$ and proposition $\mathrm{p}$, either:

1. $\mathrm{S}$ believes that $\mathrm{p}$ (represented as 'Bsp'); or

2. S believes that $\sim p$ ('Bs p'); or

3. S neither believes that $\mathrm{p}$ nor believes that $\sim \mathrm{p}$ (' $\sim \mathrm{Bsp} \bullet \sim \mathrm{Bs} \sim \mathrm{p}$ ').

To make the discussion concrete, let ' $\mathrm{g}$ ' be the proposition that God exists. Either (1) S believes that God exists ('Bsg'), (2) S believes that God does not exist ('Bs g'), or (3) S neither believes that God exists nor believes that God does not exist (' $\sim \mathrm{Bsg} \bullet \sim \mathrm{Bs} \sim \mathrm{g}$ '). Here is a diagram of possibilities:

\begin{tabular}{lll}
\hline & Bs $\sim \mathrm{g}$ & $\sim \mathrm{Bs} \sim \mathrm{g}$ \\
\hline $\mathrm{Bsg}$ & 1. Irrationalism & 2. Theism \\
$\sim \mathrm{Bsg}$ & 3. Atheism & 4. Agnosticism \\
\hline
\end{tabular}

A theist is someone who believes that God exists and does not believe that God does not exist. An atheist is someone who believes that God does not exist and does not believe that God exists. An agnostic is someone who neither believes that God exists nor believes that God does not exist. Only an irrational person would both believe that God exists and believe that God does not exist. The reason such a person would be irrational is that it cannot (logically) be the case both that God exists and that God does not exist. Either God exists or God does not exist, and not both. (The first follows from the Law of Excluded Middle, the second from the Law of Non-Contradiction.)

Note that a theist is both a believer (in the existence of God) and a non-believer (in the non-existence of God). A theist believes that God exists and does not believe that God does not exist. An atheist, too, is both a believer (in the non-existence of God) and a non-believer(in the existence of God). An atheist believes that God does not exist and does not believe that God exists. An agnostic is a non-believer twice over: he or she neither believes that God exists nor believes that God does not exist. Since both theists and atheists are both believers and non-believers, it would be misleading to describe theists as "believers," atheists as "disbelievers," and agnostics as "non-believers." Theists are both believers and non-disbelievers. (Indeed, they are non-disbelievers because they are believers.) Atheists are both disbelievers and non-believers. (Indeed, they are non-believers because they are disbelievers.) Agnostics are both non-believers and non-disbelievers. Here is a summary:

- The theist says, "I believe that God exists and I do not believe that God does not exist." (More precisely: "I do not believe that God does not exist; indeed, I believe that God exists.")

- The atheist says, "I believe that God does not exist and I do not believe that God exists." (More precisely: "I do not believe that God exists; indeed, I believe that God does not exist.")

- The agnostic says, "I do not believe that God exists and I do not believe that God does not exist."

Let us return to the generic statement ' $\mathrm{S}$ believes that $\mathrm{p}$ '. We have seen that there are three possible relations between a believing subject $(\mathrm{S})$ and a proposition $(\mathrm{p})$. Each of the three relations is compatible with the proposition (p) being either true or false. Here are examples of each (Keith and Jethro are as before; let Artok be someone who knows little or nothing about American history):

1. Bsp • p (belief in a truth): Keith believes that Donald J. Trump is the 45th president.

2. Bsp $\bullet \sim$ p (belief in a falsehood): Jethro believes that Hillary Rodham Clinton is the 45th president.

3. Bs $\sim p \cdot p$ (disbelief in a truth): Jethro believes that Donald J. Trump is not the 45th president.

4. Bs p $\sim \sim p$ (disbelief in a falsehood): Keith believes that Hillary Rodham Clinton is not the 45th president. 
5. $\sim$ Bsp $\bullet \sim \mathrm{Bs} \sim \mathrm{p} \bullet \mathrm{p}$ (non-belief and non-disbelief in a truth): Artok neither believes nor disbelieves that George Armstrong Custer was born in 1839.

6. $\sim$ Bsp $\bullet \sim B s \sim p \bullet \sim p$ (non-belief and non-disbelief in a falsehood): Artok neither believes nor disbelieves that George Armstrong Custer was born in 1838.

What this shows is that the truth value of ' $\mathrm{S}$ believes that $\mathrm{p}$ ' is not determined by the truth value of ' $\mathrm{p}$ '. One can believe a truth, believe a falsehood, disbelieve a truth, disbelieve a falsehood, neither believe nor disbelieve a truth, and neither believe nor disbelieve a falsehood. Belief statements are not truth-functional. ${ }^{3}$

For the sake of completeness, and to stimulate further research, let me make one more comment on this list of six possibilities. Epistemically speaking, only possibilities 1 and 4 are good (praiseworthy). It is good (praiseworthy) to believe a truth (possibility 1) and to disbelieve a falsehood (possibility 4). It is bad (blameworthy) to believe a falsehood (possibility 2), to disbelieve a truth (possibility 3 ), neither to believe nor to disbelieve a truth (possibility 5), and neither to believe nor to disbelieve a falsehood (possibility 6).

The reason it is bad (blameworthy) to believe a falsehood (possibility 2) is that one should disbelieve a falsehood. The reason it is bad (blameworthy) to disbelieve a truth (possibility 3 ) is that one should believe a truth. The reason it is bad (blameworthy) neither to believe nor to disbelieve a truth (possibility 5) is that one should believe a truth. The reason it is bad (blameworthy) neither to believe nor to disbelieve a falsehood (possibility 6) is that one should disbelieve a falsehood.

Goodness and badness are matters of degree. It is why we have comparatives ("better," "worse") and superlatives ("best," "worst") in our language. Given that it is good (praiseworthy) to believe a truth and to disbelieve a falsehood, which is better (or more important), and why? Given that it is bad (blameworthy) to believe a falsehood and to disbelieve a truth, which is worse, and why? Which epistemic state is best? Which is worst? Does the answer depend on the content of the belief? Is there a relevant difference between the belief that God exists (for example) and the belief that dogs exist, or that Austin is the capital of Texas? There is much here that needs investigation.

\section{Conclusion}

The purpose of this essay is to explain the difference between truth-functional compound propositions and non-truth-functional compound propositions, using what I call "belief statements" as an example of the latter. My explanation of why belief statements are not truth-functional is both more thorough and (I submit) more illuminating than the explanations provided by the leading logic textbooks. The authors of these textbooks may wish to incorporate some of my suggestions into future editions. Alternatively, they may direct their students to this essay for edification.

\section{Acknowledgments}

This essay is dedicated to my beautiful and talented wife, Katherine.

\footnotetext{
3 There are other types of non-truth-functional compound statement besides belief statements. Quine (1980, pp. 20-24) lists the following: subjunctive conditionals (e.g., "If Hoover were now president, America would be at war"), "because" statements (e.g., "Jones needs quinine because he has malaria"), "and hence" statements (e.g., "Jones has malaria and hence he needs quinine"), and statements where "believes" is replaced by "doubts," "says," "denies, "regrets, " and "is surprised."
} 


\section{References}

Baronett, S. (2019). Logic. 4th ed. New York: Oxford University Press.

Copi, I. M. (1982). Introduction to logic. 6th ed. New York: Macmillan Publishing Company.

Hurley, P. J. (2016). Logic: The essentials. Stamford, CT: Cengage Learning.

Quine, W. V. O. (1980). Elementary logic. Rev. ed. Cambridge, MA: Harvard University Press. 